\title{
A Study on Prospective Teachers' Self-Efficacy Beliefs Regarding the Implementation of Constructivist Approach (A Case of Konya)
}

\author{
Iş11 Sönmez Ektem \\ Correspondence: Işıl Sönmez Ektem, Necmettin Erbakan University, Ahmet Keleşoğlu Faculty of Education, Meram, \\ Konya, Turkey
}

Received: November 29, 2015 Accepted: December 14, 2015 Online Published: January 12, 2016

doi:10.11114/jets.v4i3.1222

URL: http://dx.doi.org/10.11114/jets.v4i3.1222

\begin{abstract}
The purpose of this study was to reveal prospective teachers' perceptions and views about the implementation of the constructivist approach. The study was conducted on 528 prospective teachers in their 4th year at Necmettin Erbakan University Ahmet Keleşoğlu Education Faculty and Selcuk University Faculty of Science and Faculty of Letters in the academic year of 2014-2015 in Konya, Turkey. The mixed method, where qualitative and quantitative methods are used together, was used in the study. In collecting the quantitative data, 5-point Likert type "Self-Efficacy Scale for the Implementation of Constructivist Approach", which was developed by Evrekli, Şaşmaz-Ören and İnel (2010), was used whereas a semi-structured interview form consisting of two questions was used in collecting the qualitative data. It is justified to say, on the basis of the data obtained from the study, that prospective teachers' self-efficacy beliefs regarding the planning of lessons according to the constructivist approach, forming a process of teaching and learning as well as a process of testing and evaluation and creating a learning environment were high. Moreover, it was concluded that prospective teachers' beliefs concerning the implementation of the constructivist approach did not exhibit variation by the type of faculty where they were receiving education and by gender but that they varied by their academic mean scores.
\end{abstract}

Keywords: constructivist approach, self-efficacy, prospective teacher

\section{Introduction}

Differences in the point of view concerning the constructivist philosophy caused the traditional educational programs, which were under the influence of behaviorist theory, to undergo a change (Erdamar, Koç \& Demirel, 2008) and the educational programs in Turkey were subjected to a radical change in the 2005-2006 school year, as a result of which educational programs prepared on the basis of the behaviorist approach were replaced by the constructivist approach, in which the learner is at the center of the learning-teaching process (MEB, 2005). Constructivist approach, unlike the traditional educational ones, adopts an educational understanding where there is more than one aspect and more than one truth rather than a single aspect and a single truth (Von Glasersfeld, 1995). It is an approach concerned with information and learning rather than teaching and this approach is based on constructing the information from scratch. Initially, it was developed as an approach concerned with how learners learned information but with time it evolved into an approach concerned with how learners constructed information (Demirel, 2009). Therefore, learning approaches where the teacher assumed the role of conveying information and the students remained in a passive position lost their relevance in the face of this approach (Jenkins, 2000).

When it is viewed as a concept, it is the name of theory trying to explain how people learn and philosophically, it is a concept concerned with information and science; it tries to explain the nature of information (Arslan, 2007). Constructivism posits that information is in no way independent of a person; instead, it is a reflection of situation-specific, contextual and individual meanings (Yurdakul, 2005). The main emphasis in the constructivist approach, which is a learner-centered learning approach focuses on the assumption that learners construct meaning by establishing a connection between their past information and the new information (Henson, 2003)., is on what kind of a meaning individuals derive from the information rather than their receiving and adopting the information (Yaşar, 1998). Indeed, in constructivism, learners cannot be passive receivers of information like a sponge (Sewel, 2002); on the contrary, information is formed by individuals on the basis of their own experiences, organizations and discoveries (von Glasersfeld, 1996). In other words, it is concerned with learners' constructing information and putting it into effect (Perkins, 1999). 
The fact that the emphasis in the constructivist approach is on the learner rather than the teacher has changed the roles of the teacher and the learner during the learning process and has made it necessary that the learner takes on a more active role in the learning process (Kumar, 2006; Özden, 2005). Such a learning environment requires learners to assume more responsibility in the learning process and be more active. Indeed, in the constructivist approach, learning environments are regarded as places where questioning and investigation take place and students can receive rich learning experiences (Demirel, 2005). Learning in constructivist classes is supported by cooperation between teachers and students and high level learning and problem solving activities are encouraged. The teacher tries to establish connections between the subject and the students' lives (Rice \&Wilson, 1999; Retold by: Kaya, 2013). Learners are seen as meaning-seekers (researchers) and problem-solvers whereas teachers are seen as guides who help students construct information and discover meaning and facilitators in this process rather than individuals who transfer information (Dunlop \& Grabinger, 1996). It appears that although learners play a significant role in constructivism, teachers assume the most important role in the learning process (Horstman \& White. 2002). Indeed, Gold (2001) defines the learning principles of constructivism and the role of the teacher in this regard as creating learning situations appropriate for individuals, evaluating learners from their points of views, and knowing that permanent learning takes a long time and occurs via social interaction and as a result of a struggle (Turan \& Erden, 2010). Whereas according to Brooks and Brooks (1993), the tasks of teachers involve directing students to problems that arouse interest in the subject, construct learning through the most basic concepts, eliciting students' individual views and appreciating these views, guiding the education program in accordance with students' views and dealing with the evaluation of learning within the scope of teaching (Özerbaş, 2007).

In brief, the responsibility of the teachers in the constructivist approach is not to spread information but to encourage students to construct information, and provide them with opportunities to do this, serve as guides to learners, make suggestions to them and focus on learning (Erdem, Demirel, 2002). As can be seen, the constructivist approach has caused extensive changes with regard to the roles and duties of teachers and students within the classroom and at the same time led teachers to revise their responsibilities concerning the learning process. In this context, the changes that have been made in the programs in recent years are based on constructivist approach and accordingly require that teachers, who are implementers of programs, be equipped with certain qualities.

Teachers are key people in the effective implementation of a teaching program the success of a teaching program depends largely on teachers' adopting the program and implementing it in accordance with the goal set (Gömleksiz, 2007). In this context, it is thought that determination of the levels of pre-service teachers' beliefs in their self-efficacy with regard to the implementation of the constructivist approach and their views about the constructivist approach is important in terms of revealing the profile of teachers of the future. Therefore, the purpose of this study was determined as revealing the pre-service teachers' self-efficacy beliefs regarding the implementation of the constructivist approach and their views about the constructivist approach. Answers to the following research questions were sought within the framework of this overall objective:

1. What are the levels of self-efficacy perceptions of prospective teachers attending the Education Faculty and the prospective teachers attending Faculties of Science and Faculties of Letters regarding the implementation of the constructivist approach (planning the course, the process of learning and teaching, the process of testing and evaluation, and creation of a learning environment)?

2. Do prospective teachers' self-efficacy perceptions regarding the implementation of the constructivist approach vary by faculty, gender and academic mean score?

3. What are the views of the prospective teachers concerning the implementation of the constructivist approach?

\section{Method}

\subsection{Research Model:}

The mixed method, where quantitative and qualitative data are used together, was used in this study. The mixed method is based on collecting quantitative and qualitative data together or consecutively, analyzing them and combining the information collected (Creswell, Plano-Clark, Gutmann \& Hanson, 2003). In collecting the quantitative data, "Self-Efficacy Scale for the Implementation of Constructivist Approach", which was developed by Evrekli, Şaşmaz-Ören \& İnel (2010), was used.

On the other hand, interviews were held with the pre-service teachers to collect qualitative data.

\subsection{Research Group}

The research group of the study consisted of 528 4th-year students at Necmettin Erbakan University Education Faculty and Selcuk University Faculty of Science and Faculty of Letters who completed their pedagogical formation training in the 2014-2015 academic year 281of the prospective teachers were attending the Education Faculty and 247 were 
attending the Faculty of Science and Faculty of Letters.

On the other hand, interviews were held with 7 prospective teachers concerning the qualitative dimension of the study.

\subsection{Data Collection Tools}

5-point Likert type "Self-Efficacy Scale for the Implementation of Constructivist Approach", which was developed by Evrekli, Şaşmaz-Ören and İnel (2010), was used to determine the self-efficacy beliefs of prospective teachers concerning the implementation of the constructivist approach. The scale consisted of 41 items based on four factors and their reliability coefficient was specified as .96 (Evrekli, Şaşmaz-Ören, \& İnel, 2010). The sub-dimension of self-efficacy belief concerning course planning based on the constructivist approach consisted of 8 items whereas the sub-dimension of self-efficacy belief with regard to the learning-teaching process concerning the constructivist approach consisted of 10 items. The sub-dimension of self-efficacy belief about the testing and evaluation process regarding the constructivist approach consisted of 12 items whereas the sub-dimension of self-efficacy belief about creating a learning environment in the constructivist approach consisted of 11 items.

Moreover, a demographic information form was used to determine the demographic characteristics of the prospective teachers.

Two semi-structured questions were used in the qualitative dimension of the study. The questions used in the qualitative dimension were prepared by the researcher and these questions were assessed to determine to what extent they served the objective, after which appropriate ones were selected. Finally, qualitative questions were given their final form after taking expert opinion.

\subsection{Analysis of the Data}

Descriptive statistical techniques and multivariate variance analysis (MANOVA) were used to analyze the data obtained. Before the implementation of MANOVA, it was investigated whether some assumptions were met or not. Mahalanobis distance values were calculated and multivariate outliers were examined $\left(\chi_{(4)}^{2}=18.47 ; p<.001\right) .13$ extreme values affecting the multivariate normal distribution were identified and these values were excluded from the data set. On the other hand, homogeneity of the variances was investigated using the Box $\mathrm{M}$ test $\left(\mathrm{F}_{(110,296.18 .64)}=1.17, p>.05\right)$. Finally, scatter diagram matrices were formed to investigate the relationships within each dependent variable and it was understood that multivariate linearity was largely ensured. According to the results obtained, it was understood that basic assumptions of MANOVA were met.

The views were taken in face-to-face interviews so as to conduct an in-depth investigation of the data obtained from the interview questions. After the views were transcribed, they were sent to the prospective teachers to be confirmed by them. One of the qualitative data analysis techniques, namely descriptive analysis was used in order to analyze the data obtained from the interviews. While the descriptive analysis was being conducted, the data obtained were summarized and interpreted according to the themes previously determined. The prospective teachers, whose views were taken within the framework of research ethics, were encoded and defined. P.T. stands for prospective teachers whereas the subsequent number $(1,2 .$.$) represents the respective code of the prospective teacher interviewed.$

\section{Results}

This section involves findings that are in parallel with the sub-goals of the study. In order to establish more clearly the research findings were presented in the form of findings about the quantitative data first and then findings about the qualitative data.

\subsection{Quantitative Findings of the Study}

Mean scores and standard deviation values which senior prospective teachers attending the Education Faculty, Faculty of Science and Faculty of Letters received from Self-Efficacy Belief Scale for the Implementation of Constructivist Approach are given in Table 1. When Table 1 is examined, it is understood that the self-efficacy beliefs of the students at the Education, Science and Letters Faculties regarding lesson planning, the learning and teaching process, the process of testing and evaluation and creation of a learning environment are high. 
Table 1. Mean and Standard Deviation Values Which Prospective Teachers Attending Education Faculty and Faculty of Science and Faculty of Letters Received from the Self-Efficacy Belief Scale for the Implementation of Constructivist Approach

\begin{tabular}{|c|c|c|c|c|c|c|c|c|c|c|c|c|}
\hline \multirow{2}{*}{ Type of Program } & \multicolumn{3}{|l|}{ LP } & \multicolumn{3}{|l|}{ LTP } & \multicolumn{3}{|l|}{$\mathrm{TE}$} & \multicolumn{3}{|l|}{ LE } \\
\hline & $\mathrm{M}$ & $\mathrm{M} / \mathrm{I}$ & Ss & $\mathrm{M}$ & $\mathrm{M} / \mathrm{I}$ & Ss & $\mathrm{M}$ & $\mathrm{M} / \mathrm{I}$ & $\mathrm{Ss}$ & $\mathrm{M}$ & $\mathrm{M} / \mathrm{I}$ & Ss \\
\hline Education Faculty & 31,11 & 3,89 & 4,03 & 38,85 & 3,89 & 5,00 & 46,29 & 3,88 & 6,83 & 44,72 & 4,07 & 5,86 \\
\hline $\begin{array}{l}\text { Faculty of Science } \\
\text { and Letters }\end{array}$ & 31,46 & 3,93 & 3,34 & 40,00 & 4,00 & 4,54 & 47,45 & 3,95 & 5,77 & 45,49 & 4,14 & 5,23 \\
\hline
\end{tabular}

X/M: Mean/Number of Items, LP: Self-efficacy belief regarding lesson planning, LTP: Self-Efficacy belief regarding the learning-teaching process, TE: Self-efficacy belief regarding the process of testing and evaluation, LE: Self-efficacy belief regarding creation of a learning environment

When Table 1 is examined, as far as the mean scores are concerned, it is seen that mean score of the prospective teachers attending the Education Faculty from the sub-dimension of self-efficacy belief regarding lesson planning is 31.11 whereas mean score of the prospective teachers attending the other faculties is 31.46 . In the sub-dimension of self-efficacy belief regarding the process of learning and teaching, the mean score of the prospective teachers attending the Education Faculty is 38.85 whereas the mean score of the prospective teachers attending the other faculties is 40.0. In the sub-dimension of the self-efficacy belief regarding the process of testing and evaluation, the mean score of the prospective teachers graduating from the Education Faculty is 46.29 whereas mean score of the prospective teachers graduating from the other faculties is 47.45 . In the sub-dimension of self-efficacy belief regarding the creation of a learning environment, the mean score of the prospective teachers graduating from the Education Faculty is 44.72 whereas the mean score of the prospective teachers graduating from the other faculties is 45.49 .

According to the mean scores which were obtained by dividing the scores received from the scale by the number of items, it is possible to say that the self-efficacy beliefs of the prospective teachers regarding lesson planning, learning-teaching process and testing and evaluation processes and creation of a learning environment based on the constructivist approach are high. At the same time, it can also be said that the self-efficacy beliefs of the prospective teachers based on the constructivist approach are the highest in the testing and evaluation process whereas the self-efficacy beliefs of the prospective teachers are the lowest in the lesson planning sub-dimension.

MANOVA test was conducted to determine whether or not the scores received from Self-Efficacy Belief Scale for the Implementation of Constructivist Approach varied by gender, academic mean score and the type of program. The results obtained are given in Table 2.

Table 2. MANOVA Results Conducted to Analyze the Scores Obtained from the Self-Efficacy Belief Scale for the Implementation of the Constructivist Approach According to Faculty, Gender and Academic Mean Score

\begin{tabular}{llllll}
\hline Variables & $\lambda$ & $\mathrm{F}$ & Hypothesis Sd & Error Sd & $\mathrm{P}$ \\
\hline Faculty &, 99 & 1,61 & 4,00 & 500,00 &, 17 \\
Gender &, 99 &, 79 & 4,00 & 500,00 &, 53 \\
Academic Mean Score &, 97 & 2,22 & 8,00 & 1000,00 &, 02 \\
\hline
\end{tabular}

When Table 2 is examined, it is seen that the scores obtained from the Self-Efficacy Belief Scale for the Implementation of Constructivist Approach did not vary by gender and the type of program but that they varied significantly by the academic mean score. ANOVA was conducted to see which dependent or independent variables contributed to multivariate significance. The results obtained are given in Table 3.

Table 3. ANOVA Results Conducted to Analyze the Scores Received from the Self-Efficacy Belief for the Implementation of the Constructivist Approach According to Academic Mean Score

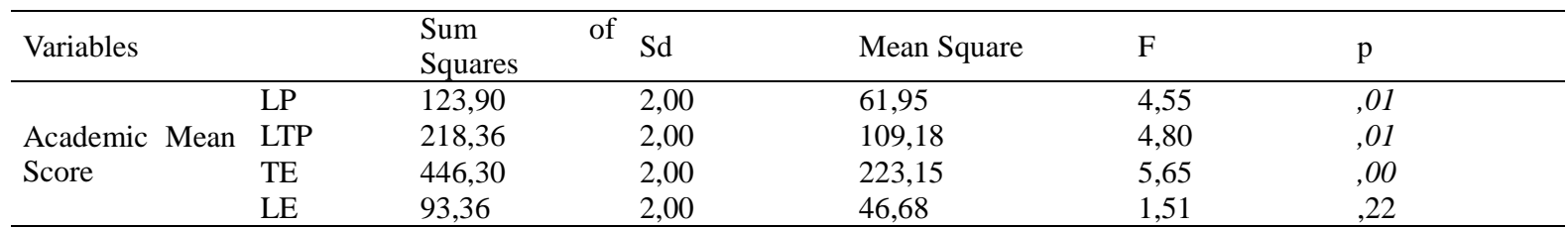

LP: Self-efficacy belief regarding lesson planning, LTP: Self-Efficacy belief regarding the learning-teaching process, TE: Self-efficacy belief regarding the process of testing and evaluation, LE: Self-efficacy belief regarding creation of a learning environment

When Table 3 is examined, it is seen that the self-efficacy beliefs of the prospective teachers who participated in the study regarding the creation of a learning environment did not vary significantly by their academic mean scores but that their self-efficacy beliefs varied significantly by lesson planning, and forming a learning and teaching process and a testing and evaluation process. According to the result of the Tukey HSD test, which was conducted to see the source of 
the variation, it was understood that the self-efficacy beliefs of the students with mean scores between 2.5-2.99 and 3-3.49 regarding lesson planning $\left(X_{2.5-2.99}=31,46 ; X_{3-3.49}=31,59\right)$ and the learning-teaching process $\left(X_{2.5-2.99}=39,38\right.$; $\left.X_{3-3.49}=40,20\right)$ were higher than the self-efficacy beliefs of the prospective teachers with mean scores between 2 and 2.49 regarding lesson planning $\left(\mathrm{X}_{2-2.49}=30,00\right)$ and the learning-teaching process $\left(\mathrm{X}_{2-2.49}=37,81\right)$. Moreover, it was found that the self-efficacy beliefs of the prospective teachers with mean scores between 3 and 3.49 regarding the process of testing and evaluation $\left(\mathrm{X}_{3-3.49}=48,09\right)$ were higher than those of the prospective teachers with mean scores between 2 and $2.49\left(\mathrm{X}_{2.5-2.99}=44,87\right)$. According to the results obtained, it is possible to say that regarding the implementation of the constructivist approach, the self-efficacy beliefs of the prospective teachers with higher academic achievement are higher.

\subsection{Qualitative Findings of the Study}

The qualitative dimension of the study aimed to obtain an in-depth insight into the views of the prospective teachers regarding the constructivist approach.

The prospective teachers participating in the study were asked the question "what does the constructivist approach mean to you?" and the responses they gave were summarized in Table 4.

Table 4. Prospective Teachers' Definitions Regarding the Constructivist Approach

\begin{tabular}{lll}
\hline Theme & Definitions Regarding Constructivism & Frequency \\
\hline Sub-Themes & It is student-centered & 3 \\
& It involves interaction in the classroom & 1 \\
\cline { 2 - 3 } & $\begin{array}{l}\text { It is concerned with construction of } \\
\text { information }\end{array}$ & 2 \\
& It is meaningful learning & 1 \\
\hline
\end{tabular}

As can be seen in Table 4, three of the prospective teachers who participated in the study described constructivism as "student centered"; one of "communication in the classroom",one of "construction of information" and one of "effective learning".

The participant with the code P.T.1 described constructivism as follows: "It is a student centered approach. Programs to be implemented are prepared in cooperation with the students and in accordance with their interests and abilities". The participant with the code P.T.7 described it as follows: "It is a student centered approach advocating that each student learns differently and that attention should be paid to the individual differences among students". The participant with the code P.T.4 who described constructivism as construction of information also said that "constructivism means students' accessing information by themselves". Likewise, the participant with the code P.T.5 described it as follows: "It means that information is specific to individuals. Everyone lives differently, so information of everyone is also different. Here, it means conducting classes using that information".

The participant with the code P.T.2 who described it as meaningful learning stated the following: "This approach is very different from the previous one. It requires us pre-service teachers to use a lot of materials. We serve as guides and students learn meaningfully".

The prospective teachers were asked "Do you think you will encounter problem/s while implementing the constructivist approach in the classroom? Why/Why not? And the responses elicited were summarized in Table 5.

Table 5. According to the prospective teachers, problems that could be encountered during the implementation of the constructivist approach in the classroom

\begin{tabular}{lll}
\hline Theme & Problems encountered in the implementation of the constructivist approach & Frequency \\
\hline Sub-Themes & Problems concerning classroom management & 5 \\
& Teachers' feeling themselves inefficient with regard to planning & 2 \\
& Physical inefficiency & 1 \\
\hline
\end{tabular}

When Table 5 is examined, it is observed that the biggest problem concerning the implementation of the constructivist approach is related to classroom management. In this regard, the participant with the code Ö.A.6 expressed his views as follows: "I can implement this approach easily unless the classroom size is too big. I do not think I can implement it in classrooms with forty students because as the number of students increases, communication decreases, and implementation of the approach becomes harder". P.T.5, on the other hand made the following statements: "I believe that the biggest problem with this approach will be related to the number of students. Constructivism proposes that students should be active but when the overall situation of schools is taken into consideration, it is seen that classrooms are overcrowded. Students cannot be active in crowded classrooms." The participant encoded as P.T.3 spoke as follows: "In crowded classrooms, participation of every student in classes, conducting classes through activities and allowing every student to have a say may lead to chaos. I think it will make teacher's control of the classroom harder. If the number of students in classrooms is reduced, then implementation of it will become easier". As can be seen above, 
pre-service teachers think that the most important problem that can be experienced with the regard to the implementation of the constructivist approach is in the field of classroom management and that the main source of this problem regarding classroom management concerns large classroom sizes. In this regard, a pre-service teacher said that if the number of students in classrooms was reduced, then constructivism could be implemented more easily.

Two important sub-problems regarding the physical inadequacy of classrooms were found to be large classroom size and insufficiency of classroom materials. The participant with the code P.T.1 said the following in this regard: "I think it would be difficult to bring into classrooms the materials that appeal to more than one sensory organ. The nature and the situation of the classroom which I will teach are important. Classrooms are small. Spaces need to be large and adequate for this approach."

The participant with the code P.T.7, who thought he might experience problems with regard to making lesson plans compatible with the constructivist approach, made the following statements: "I do not think I can make a lesson plan based on the constructivist approach. I think the plans on the internet are inadequate" On the other hand, the participant with the code P.T.4 made the following comment: "I think problems can be experienced in some topics. It is difficult to prepare plans according to students' needs, interests and attitudes".

\section{Discussion and Conclusion}

In this study, prospective teachers' self-efficacy beliefs regarding the implementation of the constructivist approach and their views with regard to the implementation of the constructivist approach were investigated.

When the results obtained from the study are examined, it is justified to conclude that prospective teachers' self-efficacy beliefs concerning lesson planning based on the constructivist approach, learning-teaching and testing-evaluation processes and creation of a learning environment are high. The research findings of Demir, Önen, Şahin (2012), Eskici (2013), Fidan, Duman (2014), Özenç, Doğan (2012), Kaya (2013), Kasapçığlu, Duban (2012) indicate that prospective teachers regarded themselves as efficient with regard to the implementation of the constructivist approach are in support of our findings.

Balc1 (2005) defines self-efficacy as individuals' judgments about themselves regarding their capacity to organize activities required to fulfil a certain performance and implement it successfully. Zimmerman (2000), on the other hand, defines self-efficacy as individuals' confidence in their ability and states that even if they have adequate skills and information, they may fail when they have doubts about their performance. In this context, if prospective teachers, who are implementers of programs prepared on the basis of the constructivist approach, have high self-efficacy beliefs about the implementation of the constructivist approach, this can be taken to mean that they will be effective in implementing the constructivist approach in their classes.

When prospective teachers' mean scores from the sub-dimensions (lesson planning, learning-teaching process, testing and evaluation process, and creation of a learning environment) regarding the implementation of the constructivist approach are examined, it is justifiable to conclude that their self-efficacy beliefs concerning the testing and evaluation process are higher compared with the others. However, in his study, Çayak (2014) states that the dimension where the teachers feel themselves most inefficient is alternative evaluation; likewise, Eskici (2013) concludes that teachers regard themselves least inefficient in the alternative evaluation sub-dimension. The mean scores of the pre-service teachers concerning lesson planning based on the constructivist approach can be said to be at the lowest level. This finding of our study is in parallel with the research results of Kasapçığlu and Duban (2012). Indeed, according to the qualitative findings of the study, some pre-service teachers stated that they found themselves inefficient especially in regard to planning lessons.

It was concluded in our study that prospective teachers' self-efficacy beliefs concerning the implementation of the constructivist approach did not vary by the gender variable. This finding of our study is in parallel with the research results of Özenç, Doğan (2012), Fidan, Duman (2014) and Kaya (2013) and Özenç (2009). The fact that prospective teachers' self-efficacy beliefs regarding the implementation of the constructivist approach did not vary by the gender variable may have resulted from the fact that pre-service teachers receive the same education in the same classrooms.

According to another finding of our study, prospective teachers' self-efficacy beliefs regarding the implementation of the constructivist approach did not exhibit a significant variation by the variable of type of school. Research findings of Coşkun (2012), Fidan, Duman (2014) and Kaya (2013) seem to be in support of our finding. However, this findings of this study is contradiction with the results of Özenç (2009) and Özenç, Doğan (2012), where it was found that prospective teachers' beliefs concerning the implementation of the constructivist approach varied by the type of school finished, that the highest mean score belonged to the graduates of the Education Institute, followed by the Education Faculty and other faculties.

As a result of the interviews held with the prospective teachers, the conclusion that prospective teachers defined the 
constructivist approach as student-centered and involving construction of information, effective learning and interaction in classroom seems to indicate that they have adequate information about constructivism. In Kaya (2013)'s study, the views of form teachers regarding the constructivist approach were expressed as follows: it is necessary for permanent learning, and it involves construction of information as well as learning by doing and experiencing.

While the prospective teachers were revealing their views concerning the constructivist approach, all of the prospective teachers who participated in the interview stated that they might encounter problems during the implementation of the constructivist approach. It was stated that these problems could emerge mostly in regard to classroom management and that this could result from crowded classrooms. Insufficiency of materials, small classroom size and inadequacy regarding planning were expressed as other reasons.

\section{Recommendations}

Based on the results of our study, it is recommended that although prospective teachers' self-efficacy perceptions about the implementation of the constructivist approach are high, class hours in education faculties based on the implementation of the constructivist approach should be increased given the place and significance of constructivism in the program. Prospective teachers should be enabled to prepare plans in accordance with the requirements of the constructivist approach and obtain information about how to implement those plans. Classroom size should be reduced based on the views of prospective teachers so that the constructivist approach can be used more effectively.

In future studies, prospective teachers' self-efficacy beliefs concerning the implementation of the constructivist approach and how effectively they perform in implementing this approach can be investigated.

\section{References}

Arslan, M. (2007). Eğitimde Yapılandırmacı Yaklaşımlar. Ankara Üniversitesi Eğitim Bilimleri Fakültesi Dergisi, 40(1), 41-61. http://dx.doi.org/10.1501/egifak_0000000150

Balcı, A. (2005). Açıklamalı Eğitim Yönetim Terimleri Sözlüğü. Ankara: Tek Ağaç Basım Yayım, Dă̆ııım.

Brooks, J. G., \& Brooks, M. G. (1993). In search of understanding: The case for constructivist classrooms. Alexandria: VA: Association for Supervision and Curriculum Development

Çayak, M. (2014). İlkokul Öğretmenlerinin Yapılandırmacı Yaklaşımı Uygulamaya Yönelik Tutumları İle Özyeterlikleri Arasındaki İlişki. Mehmet Akif Ersoy Üniversitesi Ĕ̆itim Fakültesi Dergisi, 31, 88-110.

Coşkun, M. K. (2012). Din Kültürü ve Ahlak Bilgisi Öğretmenlerinin Yapılandırmacı Yöntem Yeterliliklerinin Çeşitli Değişkenler Açısından İncelenmesi. Eğitim ve Öğretim Araştırmaları Dergisi Journal of Research in Education and Teaching, 1(4).

Creswell, J. W., Planoclark, V. L., Gutmann, M. L., \& Hanson, W. E. (2003). “Advanced Mixed Methods Research Design", Hand Book of Mixed Methods: in Social \& Behavioral Research, Ed.: Abbas Tashakkori and Charles Teddlie, California: SAGE Publications Inc., 209-240.

Demir, S., Önen, F., \& Şahin, F. (2012). Fen Bilgisi Öğretmen Adaylarının Yapılandırmacı Yaklaşımı Uygulamaya Yönelik Öz Yeterlilik İnanç Düzeylerinin Belirlenmesi Üzerine Bir Araştırma. X. Ulusal Fen Bilimleri ve Matematik Ĕgitimi Kongresi, Niğde.

Demirel Ö. (2009). Öğretme Sanatı. Pegem Yayınevi, Ankara

Demirel, Ö. (2005). Kuramdan Uygulamaya Eğitimde Program Geliştirme. (7. Baskı). Ankara: Pegem-A Yayınc1lı.

Dunlop, J. C., \& Grabinger, R. S. (1996). Rich environments for the active learning in higher education. Wilson, G. B. (Ed.). Constructing learning environments: Case studies in instructional design. Englewood Cliffs, New Jersey: Educational Technology Publications

Erdamar, K. G., \& Demirel, M. (2008). Yapılandırmacı Öğrenme Yaklaşımının Duyuşsal ve Bilişsel Öğrenme Ürünlerine Etkisi. Türk Eğitim Bilimleri Dergisi, 6(4), 629-661.

Erdem, E., \& Demirel, Ö. (2002). Program Geliştirmede Yapılandırmacılık Yaklaşımı. Hacettepe Üniversitesi Eğitim Fakültesi Dergisi, 23, 81-87.

Eskici M. (2013). İlköğretim Öğretmenlerinin Yapılandırmacı Yaklaşıma İlişkin Öz Yeterlik Algıları ile Tutumları. Abant İzzet Baysal Üniversitesi Eğitim Bilimleri Enstitüsü, Yayınlanmamış Doktora Tezi

Eskici, M. (2013). İlköğretim Öğretmenlerinin Yapılandırmacı Yaklaşıma İlişkin Özyeterlik Algıları ile Tutumları. Yayımlanmamış Doktora Tezi, Abant İzzet Baysal Üniversitesi Eğitim Bilimleri Enstitüsü, Bolu.

Evrekli, E., Şaşmaz Ö. F., \& İnel, D. (2010). Pre-Service Primary Teachers' Self-Efficacy toward the Constructivist Approach and Their Opinions About Their Efficacy Levels. Greece, Athens: 12th Annual International Conference 
on Education (24-27 May1s).

Fidan N. K., \& Duman, T. (2014). Sınıf Öğretmenlerinin Yapılandırmacı Yaklaşımın Gerektirdiği Niteliklere Sahip Olma Düzeyleri. Eğitim ve Bilim, 39(174), 143-159.

Gold, S. (2001). A Constructivist Approach to Online Training for Online Teachers. Journal of Asynchronous Learning Networks, 5(1). http://www.aln.org/publications/jaln/v5n1/v5n1_gold. asp. adresinden alınmıştır [10.8.2015]

Gömleksiz, M. N. (2007). Yeni İlköğretim Programına İlişkin Öğretmen Görüşlerinin Çeşitli Değişkenler Açısından Değerlendirilmesi. Eurasian Journal of Educational Research, 27, 69-82.

Henson, K. T. (2003). Foundations For Learner-Centered Educational: A Knowledge Base. Education, 124(1), 5-16.

Horstman, B., \& White, W. G. (2002). Best Practice Teaching in College Success Courses: Integrating Best Practice Teaching Methods into College Success Courses. The Journal of Teaching and Learning, 6(1), 6-15.

Jenkins, E. W. (2000). Constructivism in School Science Education: Powerful Model or the Most Dangerous Intellectual Tendency? Science and Education, 9, 599-610. http://dx.doi.org/10.1023/A:1008778120803

Kasağçığlu, K., \& Duban, N. (2012). Sınıf Öğretmeni Adaylarının Yapılandırmacı Yaklaşımı Uygulamaya Yönelik Öz Yeterlik İnançlarını Yordayan Bir Faktör Olarak Yapılandırmacı Yaklaşıma Yönelik Tutumları (Afyonkarahisar İli Örneği) Mersin Üniversitesi Eğitim Fakültesi Dergisi, 8(2), 85-96.

Kaya, B., Topçu, E., \& Kop, Y. (2014). 7. Sınıf Sosyal Bilgiler Çalışma Kitaplarının Yapılandırmacı Öğrenme Yaklaşımı Açısından İncelenmesi. Turkish Studies - International Periodical for the Languages, Literature and History of Turkish or Turkic, 9/5 1327-1340.

Kaya, N. (2013). Sinıf Öğretmenlerinin Yapılandırmacıllğa Yönelik Tutumları ve Yapılandırmacılı̆̆ Uygulamaya İlişkin $\ddot{O} z$-Yeterlik İnançları (Afyonkarahisar İli Örneği). Afyon Kocatepe Üniversitesi, Sosyal Bilimler Enstitüsü, İlköğretim Anabilim Dalı, Yayınlanmamış Yüksek Lisans Tezi

Kumar, M. (2006). Constructivist Epistemology in Action. The Journal of Educational Thought, 40(3), 247-261.

Özden, Y. (2005). Öğrenme ve öğretme. Ankara: Pegem A Yayıncıllk

Özenç M. (2009). Sınıf Öğretmenlerinin Yapılandırmacı Yaklaşım ile İlgili Yeterlik Düzeylerinin İncelenmesi. Marmara Üniversitesi Eğitim Bilimleri Enstitüsü, Yayınlanmamış Yüksek Lisans Tezi, İstanbul

Özenç, M., \& Doğan, C. (2012). Sınıf Öğretmenlerinin Yapılandırmacı Yaklaşım Yeterlik Düzeylerinin Belirlenmesi. Abant İzzet Baysal Üniversitesi Ĕ̈itim Fakültesi Dergisi, 12(1), 67-83.

Özerbaş, M. A. (2003). Yapılandırmacı Öğrenme Ortamının Öğrencilerin Akademik Başarılarına ve Kalıcılığına Etkisi. Türk Ĕ̈itim Bilimleri Dergisi, Güz, 5(4), 609-635.

Perkins, D. N. (1999). The many faces of constructivism. Educational Leadership, 57(3), 6-11.

Rice, M. L., \& Wilson, E. K. (1999). How Technology Aids Constructivism in the Social Studies Classroom. The Social Studles. http://dx.doi.org/10.1080/00377999909602388

Sewell, A. (2002). Constructivism and student misconceptions: Why every teacher needs to know about them. Australian Science Teacher Journal, 48, 24-29.

Turan, H., \& Erden, M. (2010). Sınıf Öğretmenlerinin Yapılandırmacı Ortam Düzenleme Becerilerinin İncelenmesi. e-Journal of New World Sciences Academy, 5(4).

Von, G. E. (1995b). Radical Constructivism. Usa: The Falmer Press.

Von, G. E. (1996). Introduction: Aspect of Constructivism. C. T. Fosnot, (Ed.). Constructivism: Theory, Perspectives, And Pracrice, (3-7). Usa: Teacher College Press.

Yaşar, Ş. (1998). Yapısalcı Kuram ve Öğrenme-Öğretme Süreci. Anadolu Üniversitesi Eğitim Fakültesi Dergisi, 8(1-2), 68-75.

Yurdakul, B. (2005). Yapılandırmacılı, Ö. Demirel (Ed.) 88 (ss. 39-65). 1. Baskı, Ankara: Pegem A Yayınc1lı.

Zimmerman, B. J. (2000). Self-efficacy: An essential motive to learn. Contemporary Educational Psychology, 25, 82-91. http://dx.doi.org/10.1006/ceps.1999.1016

\section{$(\mathrm{Cc}) \mathrm{BY}$}

This work is licensed under a Creative Commons Attribution 3.0 License. 